\title{
Caste Memes: Power, Politics of Memory, and the Historical Imaginary
}

\section{Ritwik Balo*}

English Presidency University, Kolkata, India

\begin{abstract}
Two great dictators of the first half of the 20th century, Mussolini and Hitler, won the political consent of their people, i.e, Italians and Germans, above all, by pandering to an abstract idea - the sense of history. Even as we move on into the 21st century, as a wave of fundamentalism engulfs many parts of the world, it strikes us hard as we observe that political consent is won by not promising a future to a people, but by reminding them of a perfect past which the populace can only imagine, and will cherish in so doing. At the level of corporeal performativity, it seems (and history is evident), people will protect this imaginary sense of history at all costs. The conclusion of this study is that it is a craving, not for a utopian future but, very often, for a utopian past that drives human political action. Human beings, this essay will try to establish, even as they move towards the future whilst living in the present, want a memory of a great flawless past to be present in what we will henceforth call the 'historical imaginary'. Also, this paper tries to study (by looking at an anthropological case study involving the Pramalai Kallar subcaste of South India) how Collective Memory of Castes and Subcastes is subject to politics and how such politicised memory appeals to the historical imaginary insofar as it evokes the lower castes to not only speak but also actively participate in the rhetoric of populism, and contribute to the promise of the return of a Utopia now bygone.
\end{abstract}

"The struggle of man against power is the struggle of memory against forgetting." - Milan Kundera, The Book of Laughter and Forgetting.

Keywords: Caste; Memory; Meme; Mimesis; Collective Memory; Historicist vulnerability; Historical imaginary

\section{Historical Imaginary}

Two great dictators of the first half of the 20th century, Mussolini and Hitler, won the political consent of their people, i.e, Italians and Germans, above all, by pandering to an abstract idea - the sense of history ${ }^{1}$. Even as we move on into the 21 st century, as a wave of fundamentalism engulfs many parts of the world, it strikes us hard as we observe that political consent is won by not promising a future to a people, but by reminding them of a perfect past which the populace can only imagine, and will cherish in so doing. At the level of corporeal performativity, it seems (and history is evident ${ }^{2}$ ), people will protect this imaginary sense of history at all costs. The conclusion of this study is that it is a craving, not for a utopian future but for a utopian past that drives human political action. Human beings, this essay will try to establish, even as they move towards the future whilst living in the present, want a memory of a great flawless past to be present in what we will henceforth call the 'historical imaginary'. Also, this paper tries to study (by looking at anthropological case studies) how Collective Memory of Castes and Subcastes is subject to politics and how such politicised memory appeals to the historical imaginary insofar as it evokes the lower castes to not only speak but also participate in the rhetoric of Populism and the promise of the return of a Utopia now bygone.

\section{Collective Memory and Social Behavior}

Memory, to begin with, is what we are. For Borges, "We are our memory, / we are that chimerical museum of shifting shapes, /that pile of broken mirrors" [1]. For Brian Falkner, "We are our memories....

${ }^{1}$ "Mussolini is said to want to 'return to the Italians (Italis) that Italy (Italiam) which the ancient Romans (veteres Romani) had made the light of the world"' (Lamers and Reitz-Joosse, n.d.).

${ }^{2}$ Hitler, for example, claimed to "have restored the thousand-year-old historical unity of German living space" (Kershaw), thus appealing to the historical imaginary of his countrymen. Mussolini, on the other hand reminded his fellow Italians that the Roman Empire (of which they are descendents) were the greatest force in the world (Scott 645-657) (and) that's what makes us the person we are. The sum of all our memories from the day we were born. If you took a person and replaced his set of memories with another set, he'd be a different person. He'd think, act, and feel things differently [2].

But memory is almost never personal, it is collective. Memory is a dynamic collective, never in stasis, never alone, always social, always in conversation with other memories of other individuals, and in interaction with vessels that contain memory. Collective memory, writes Haim Weinberg, "refers to the shared pool of information held in the memories of two or more members of a group. Collective memory can be shared, passed on and constructed by small and large groups" [3]. By extension, "A 'collective memory', as a set of ideas, images, feelings about the past, is best located not in the minds of individuals, but in the resources they share. There is no reason to privilege one form of resource over another-for example, to see history books as important but popular movies as not" [4]. Since it is an "interaction of people's minds", it follows that such memory, because even the past is alwaysalready formative, must always be subject to distortion, always open to be manipulated [3]. Ken Eisold points out, "each time we remember something, we are reconstructing the event, reassembling it from traces throughout the brain" [5]. Since we can never completely trust our memories, no matter how confident we are about them, their shapes can be shifted, shuffled to almost anything, sometimes without us noticing the shift. John Bodnar writes, "Oral historians have generally combined the memories they recorded with other kinds of records or cross-checked their interview material with data gathered from other

*Corresponding author: Ritwik Balo, English Presidency University, Kolkata, India, Tel+91-334007 4360; E-mail: ritwik5194@gmail.com

Received May 09, 2018; Accepted May 21, 2018; Published May 28, 2018

Citation: Balo R (2018) Caste Memes: Power, Politics of Memory, and the Historical Imaginary. Arts Social Sci J 9: 363. doi: 10.4172/2151-6200.1000363

Copyright: (c) 2018 Balo R. This is an open-access article distributed under the terms of the Creative Commons Attribution License, which permits unrestricted use, distribution, and reproduction in any medium, provided the original author and source are credited. 
interviews" [6]. Just like every 'utterance', for Bakhtin, is marked by 'Addressivity', we claim, all memory is marked by what we might call a historicist vulnerability. No memory is completely private. And it is the always-already social nature of memory that makes it a subject of power. "While the collective memory endures and draws strength from its base in a coherent body of people, it is individuals as group members who remember" [7]. It is on the basis of this premise, that Collective Memory affects human social behavior, we shall proceed.

\section{Memory, Mimesis, and Birth}

There are at least two ways by which birth (and by extension, Caste) is related to memory (or 'Collective Memory' to be more precise); the first is the Jungian 'Collective Unconscious' transmitted hereditarily and has been alternatively called 'genetic memory' (Treffert) while the second are Dawkins' memes transmitted culturally. Much scholarship has been done on the first and for our present purposes it should suffice to say that "the contents of the collective unconscious have never been in consciousness, and therefore have never been individually acquired, but owe their existence exclusively to heredity" (Jung 1). The second, however, shall henceforth be our primary concern. Towards the end of his 1979 book The Selfish Gene, the evolutionary biologist Richard Dawkins invented the word "meme" and recognized that a lot of human conduct came not from genes but from culture. He suggested that any non genetic conduct be called a meme and posed the question as to whether the application of genetic logic to memes can be productive (to our understanding of culture). Patrick Davison writes in this context:

"Genes determine an organism's physical characteristics... (but) are not thinking beings themselves... Memes determine the behavior of an organism. They are either taught to an organism (you go to school and learn math) or learned through experience (you stick a finger in an outlet, get shocked, understand that outlets should be avoided). While genes rely on the physical process of reproduction to replicate, memes rely on the mental processes of observation and learning. This highlights one of the critical differences between genes and memes: speed of transmission. Compared to genetic changes (which span generations upon generations), memetic changes happen in the blink of an eye (quoted in Mandiberg).

Having said that memes are transmitted culturally, the fundamental question is - what do memes have to do with birth and memory? The answer to what memes have to do with birth can be found in Bourdieu's intervention there exists, along with economic capital, a 'cultural capital $^{3}$; it is due to differences in resources (which contain memory, as previously mentioned) among social groups - in this study, Castes and Subcastes - that memes tend to vary between castes. Indian society, stratified as it is, is hierarchized not only along the lines of Class but more prominently so along the lines of Caste and importantly, within Castes themselves.

\section{But how are memes related to memory? Dawkins writes:}

"I think that a new kind of replicator has recently emerged... It is still in its infancy... but already it is achieving evolutionary change at a rate which leaves the old gene panting far behind. We need a name for the new replicator, a noun which conveys the idea of a unit of cultural transmission, or a unit of imitation. 'Mimeme' comes from a suitable Greek root... (and) I hope my classicist friends will forgive me if I abbreviate mimeme to meme. If it is any consolation, it could alternatively be thought of as being related to 'memory'... (Dawkins)."

${ }^{3}$ In sociology, the term cultural capital alludes to the social resources an individua possesses (education, intellect, style of speech and dress, etc.) often owing to birth of the individual that enable social mobility in a stratified society.
Dawkins, then, is suggesting that meme can "be thought of as being related to 'memory". Interestingly, both the words 'mimesis' and 'memory' share an etymological womb, and both derive from the word 'mimeme' [8]. To memorise is to repeatedly perform a mimesis, and it seems that memory has a mimetic basis and mimesis itself revolves around and is possible due to memory. "When we consider the "mimetic" component of remembering, we are focusing on the repetitive cultural rituals, formal traditions, and bodily habits that cause past experience to be replicated in the present as 'second nature' [9]. Irrespective of whether a 'second nature' comes into play or not, the clues from Dawkins, Johnson, Greenleaf, and Golburt suggest that there exists, between memory and mimesis, a very close and intricate bond $[8,9]$. Memes, as the 'genes-of-memory', "propagate themselves in the meme pool by leaping from brain to brain via a process which, in the broad sense, can be called imitation". Let us examine the social presence of Caste in this light by asking the questions Dawkins asks, albeit modifying them to the demands of our present needs ${ }^{4}$. To begin with, we do not know, with absolute exactitude, how the idea of Caste appeared in the meme pool. In other words, we are trying to suggest that to point towards a precise date of the beginning of the CasteSystem with exact geographical coordinates is an impossibility. We can never find out the origin, but at best, construct a genealogy as some have done before $[10,11]$. That, however, is beyond the scope of this study. In any case, the idea of Caste is very old indeed (at least, as old as the Rig Veda ${ }^{5}$ ). How does it replicate itself? Certainly "by the spoken and written word, aided by great music and great art", but also most importantly, by means of political and corporeal performativity (as we shall see). Why does it have such high survival value? Here, it must be remember that "'survival value' here does not mean value for a gene in a gene pool, but value for a meme in a meme pool". Effectively, the question means: What is it about Caste that gives it its stability and penetrance in the cultural environment? The answer would be, rather evasively, the politics of 'Collective Memory' and the fact that power, the bulk portion of it, lies in the hands of those who get lucky at birth. The alignment of Birth, Memory, Mimesis, and Caste is visible when we are able to see the following (universal?) trajectory - Birth determines Caste (however, does not necessarily affect Class. Class is economic, Caste is social. The former is determined by the amount of money one has, the later by the birth and often by the surname of the individual.), Caste then undergoes a twofold mimetic process - the first in replicating 'Caste Memory' (which comes down hereditarily through an unchanging 'Collective Unconscious' and is also affected by the constantly updating social construct, the 'Collective Memory') and the second in imitating the higher caste, as Ambedkar observes following Tarde $^{6}$.

\section{Collective Politicized Memory}

Power has everything to do with memory. To begin with the premise we have stated earlier, Power could be defined as the potential to play with someone's memories or rather with memories of entire

${ }^{4}$ In effect, we replace Dawkins' questions regarding 'God' with 'Caste'.

5The Rig Veda (x, 90,11-12) contains the following hyms on the Caste System: 11 When they divided Purușa how many portions did they make?

What do they call his mouth, his arms? What do they call his thighs and feet? 12 The Brahman was his mouth, of both his arms was the Rājanya made. His thighs became the Vaiśya, from his feet the Súdra was produced.

${ }_{6}^{6}$ Following Gabriel Tarde, Ambedkar suggests that the tendency towards enclosure among the non-Brahmin castes follows two laws of imitation. First, the imitation flows from the higher to the lower, the source of imitation enjoying prestige in the group; second the extent and the intensity of imitation varies in proportion to distance, understood in its sociological sense" (Kannabiran 129). 
social groups and even entire Nations (as in the case of Germany and Italy under the leadership of Hitler and Mussolini). And memories, it must be taken into account, can always be played with, because they are a "pile of broken mirrors". Arrange them differently, and what will show on them will be different from what was being reflected earlier. Our conclusion? Memory, like Love as Badiou says, "is always under threat" [12]. We have claimed earlier that Caste-position of a particular caste or subcaste is affected by the constantly updating social construct called the 'Collective Memory', which is, in this case a Collective Caste Memory. Here, in order to see how Collective Memory of a social group can update and contemporize itself, we will look at a case study. In her study of the Pramalai Kallar (whom she abbreviates as PK) sub-caste in present day South-India, anthropologist Zoé E. Headley observes how the Collective Memory of the PK have evolved over the years (roughly between 1966 when the French anthropologist Louis Dumont studies the PK and 2004 when up to Headley collected her data). Headley begins stating that the PK bear "next to no material traces of their presence and influence since the sixteenth-seventeenth centuries" in the Perungamanalur region [13]. "In the early 1990s, however, PK caste association leaders sought to redress the absence of any significant "historical" landmark by constructing a memorial pillar commemorating a violent confrontation in the 1920s with the British forces that left $16 \mathrm{PK}$ dead in the town of Perungamanalur. Local activists compare the Perungamanalur incident ${ }^{7}$ to the Jallianwala Bagh massacre, thereby infusing the yearly commemoration with a flavor of colonial martyrdom" [13]. Now, this event of attaching colonial-historical values to an event that originally concerned only the PK and had little 'National' importance, if any, offers several insights into the nature of Caste-Memory and its relation to Political power, and to discourse in general. The insights are as follows:

1. The intersecting point of Caste, Collective Caste Memory, and Power is Iconography. The Perungamanalur incident, which was given little attention previously, suddenly becomes an event of National importance, but more importantly, behind the scenes, an attempt is made to politicise the memory of the PK.

2. This attachment of National importance to an event previously unnoticed or neglected, appropriates, or at least attempts to do so, the PK to consciously or unconsciously participate in Nationalism. In effect, the PK are made subjects to a politics of inclusion by means of what is effectively, as Laura Nasrallah calls, a "Politics of Memory" [14]. By means of politicizing an event then, a forgotten memory of the PK is brought into the foreground, made dominant by associating it to the larger discourse of Indian Nationalism.

3. The comparison with Jallianwala Bagh gives this event, however retrospectively, the iconographic status of an event of Nationalist importance, and thereby making this sub-caste merge into present day Nationalist discourse by evoking feelings of National oneness among the PK. Thus, as far as the Caste-in-itself ${ }^{8}$ is concerned, such valediction paradoxically makes the PK participants and perhaps propellants

${ }^{7}$ The PK were classified as a criminal tribe under the Criminal Tribes Act (CTA) of the British Raj. On the 3rd of April, 1920 some PK's at Perungamanallur village confronted the British in a violent protest against the CTA resulting in more a dozen deaths of the PK. A memorial pillar at the village names 16 inhabitants who were shot dead during the incident.

${ }^{8}$ This notion, we adapt from Deleuze's difference-in-itself where difference is understood not with reference to a self-identical idea which makes difference a difference-between. Rather, Deleuze proposes a standalone entity for the different that can be accepted on its own with no referencing. In this study, we propose the concept of Caste-in-itself from my observation that a craving exists among castes and sub-castes to dissociate themselves from other social groups (often in order to claim superiority in some social or historical register). of the dominant religious framework while actually claiming to give the PK a unique (and perhaps superior?') caste identity by valorizing the Perungamanalur incident. So, the iconography and the scholarly comparison is itself problematic because at the level of rhetoric (hence at the level of politics, and thenceforth at the level of discourse) the utterances of the similarity between the events make the PK Althusserian "subjects", interpellated and included by populist ideology (which feeds on the promise of the return of a perfect past as mentioned at the beginning of this study); the irony lies that the PK claimed their own rhetoric which is/was always-already only into nationally different from popular Nationalist rhetoric by effectively segued into the same. By means of Iconographic Interpellation, Collective Caste Memory of the PK is not only evoked but also played with, politicized and thus rendered deployable for the larger rhetoric of a long lost Utopia that is to come.

We will give another example at this juncture and attempt to tie up the idea of Caste Memes, with Collective Caste Memory (hence, their Communitarian sense of history), and the Politicization of Memory. Headley notes that PK have had a special and close bond with the Muslim population of the area and that several oral narratives describe several instances of conflicts and reconciliations between the two social tribes [13].

"Fifty years ago, these narratives were used to explain why male members of this subcaste practiced circumcision (mar kalyanam), why PK women wore a jewel said to be traditionally Muslim (karugamani), and moreover, why they exchanged kin terms. Nowadays, circumcision has become largely symbolic and the karugamani jewel seen as completely out of fashion" [13].

However, the anthropologist seems to suggest that due to national and international stigmatization of Muslims, the PK have revised their history of involvement with the former. It appears that in recent years (Headley conducted her survey between 2000 and 2004), oral narratives of past closeness between the two groups has been updated in the collective consciousness of the $\mathrm{PK}$, resulting in a new Collective Memory of relationship with the Muslims where age old stories of closeness are revised, if not totally replaced, into narratives while Muslims are not as friendly to the PK as they used to be in the narratives Dumont collected in the 1960s.

"This example (of revised narrative) demonstrates a different dialogical situation between the group's self-representation and collective memory. The narratives which describe the relationship between Muslims and the PK were, at the time of fieldwork (2000-2004), in the process of being considerably altered. These transformations were discernible through comparisons with versions of the same narrative found in colonial sources and in Dumont's monograph, but also through direct observation of the discussions and debates they generated.... (The revised history is) evident in a number of transformations that reflect this growing discomfort: what once was a marriage between a Muslim man and a PK woman, for example, becomes a rape; similarly, reconciliation and exchange of symbols of respect are reimagined as theft or expulsion [13].

'The notion of a royal descent of the Pramalai Kallar is now, i.e during Headley's fieldwork, taken for granted, but largely remains devoid of narrative content. However, "At the beginning of the twentieth century, such a royal origin was not suggested, and at the time of Dumont's fieldwork the PK appeared as foot soldiers for the Chola kings (Headley 107)". It is interesting to observe that it is the craving for a royal/regal history that drives the PK (and certainly many other groups). This craving is also the historicist vulnerability which can be used for iconographic interpellation by politicizing memory. 
Citation: Balo R (2018) Caste Memes: Power, Politics of Memory, and the Historical Imaginary. Arts Social Sci J 9: 363. doi: 10.4172/21516200.1000363

The impact of these reimagining's can be clearly seen in changes in corporeal performativity of the PK towards the Muslims, but also in other behavioral registers. In other words, Dawkins' "geneof-memory", now having been through a renewed archaeology, is now programmed in a manner as to create new behavioral and per formative memes. "These examples illustrate how the collective memory of the PK can filter, modulate and recontextualize the past, thereby maintaining the coherence of the subcaste's representation of itself through time by renegotiating its subordinate position and internal divisions, strengthening old boundaries (as in the case of the dalits), but also legitimating the creation of new ones (as in the case of the Muslims) [13].

\section{Conclusion}

This paper set out to conclude that Memory which is alwaysalready Collective is very easily manipulable and thus politicizable, especially, if the memory belongs to a social group that holds a low rank in the hierarchy of Castes and Subcastes. In addition, this work has also studied how such politicized memory appeals to the historical imaginary to the point of evoking a rhetoric of populism in the voice of the lower castes. As an outgrowth of these conclusions which are based on our interpretations of the evolutionary concept of 'meme' as a signifier of social behavior and our readings of only one anthropological survey, this paper, albeit at a theoretical level (contrived with limited empirical data), reaffirms that "India," as Arjun Appadurai wrote, paraphrasing Maurice Bloch "is an excellent case of "too much" social structure, infinite hierarchy and a superabundance of the past in the present" [13-19].

\section{References}

1. Alex T (2014) Big Little Man: In Search of My Asian Self. Houghton Mifflin Harcourt.

2. Brian F (2011) Brain Jack. Reprint edition. New York: Ember.
3. Haim W (2014) The Paradox of Internet Groups Alone in the Presence of Virtual Others. London: Karnac.

4. Iwona IZ (2009) Frames of Remembrance: The Dynamics of Collective Memory. New Brunswick: Transaction.

5. Ken E (2017) Unreliable Memory. Psychology Today.

6. John B (1989) Power and Memory in Oral History: Workers and Managers at Studebaker. The Journal of American History 75: 1201-1221.

7. Maurice H (1980) The Collective Memory. New York: Harper \& Row.

8. Paul-Alan J (1994) The Theory of Architecture: Concepts Themes \& Practices. John Wiley \& Sons.

9. Monika G, Golburt L (2009) Copies: The Mimetic Component of Remembering Slavic Review 743-757.

10. Ramji BA (1948) The Untouchables: Who Were They? And Why They Became Untouchables. Amrit Book Company.

11. Louis D (1966) Homo Hierarchicus: The Caste System and Its Implications. London: Weidenfeld and Nicolson.

12. Alain B, Truong N, Peter (2012) In Praise of Love (1stedn) London: Serpent's tail, an imprint of Profile Books.

13. Zoé EH (2011) Caste and Collective Memory in South India." A Companion To The Anthropology Of India. Malden, MA: Wiley-Blackwell 98-113.

14. Laura N (2017) The Politics of Memory.

15. Kalpana K (2013) Tools of Justice: Non-Discrimination and the Indian Constitution. Routledge.

16. Ian K (2017) The Führer Myth: How Hitler Won Over The German People. Spiegel Online.

17. Han L, Reitz-Joosse B (2016) The Codex Fori Mussolini: A Latin Text of Italian Fascism. Bloomsbury Publishing,

18. Michael M (2012) The Social Media Reader. New York: New York University Press.

19. Kenneth S (1932) Mussolini and the Roman Empire. The Classical Journal 27 645-657. 